九州大学学術情報リポジトリ

Kyushu University Institutional Repository

\title{
Verification Experiments of Aerators in Aquacultural Ponds
}

Ozaki, Akinori

Institute of Tropical Agriculture, Kyushu University

Anongponyoskun, Monton

Faculty of Fisheries Kasetsart University

Sirisuay, Soranuth

Faculty of Fisheries Kasetsart University

Kaewjantawee, Panitan

Faculty of Fisheries Kasetsart University

https://doi.org/10.5109/27375

出版情報：九州大学大学院農学研究院紀要. 58 (2)，pp.427-432，2013-09. Faculty of Agriculture， Kyushu University

バージョン :

権利関係 : 


\title{
Verification Experiments of Aerators in Aquacultural Ponds
}

\author{
Akinori OZAKI*, Monton ANONGPONYOSKUN ${ }^{1}$, Soranuth SIRISUAY ${ }^{1}$ \\ and Panitan KAEWJANTAWEE ${ }^{1}$
}

\author{
Institute of Tropical Agriculture, Kyushu University, Fukuoka 812-8581, Japan
}

(Received April 26, 2013 and accepted May 9, 2013)

\begin{abstract}
An aerator, which can induce circulation, supply dissolved oxygen and improve bottom mud conditions, is one of the important equipment for aquaculture. Many of the aquacultural farmers have installed and utilized the aerator to keep better aquacultural ponds conditions and products growth. However, most of the farmers operate the aerator empirically due to lack of the criteria for usage, setting and operating of the aerator. Such empirical operation might immiserate the farmers because the management expense of the aerator must be costly. In addition, the empirical operation might impact the nature environments. Therefore, systematic operation of the aerator might be required from both economic and environment points of view.

In order to perceive the usage tendency and clarify the performance of the aerator we conducted survey on the usage of the aerator at Samut Songkram Province, Thailand. After the survey we conducted operation experiments of the aerator at Samut Songkram Fisheries Research Station, Faculty of Fisheries, Kasetsart University to verify the impacts of the aerator on water temperature and dissolved oxygen (DO) level in the ponds. From the survey results, it was clarified that most of the farmers didn't know operation way of the aerator and run the aerator continuously. However the operation experiments of the aerator indicated that the performance of the aerator was not necessarily lead the better impact for the water quality.

In this paper we discuss and propose the better operation method of the aerator based on both survey and experiments results.
\end{abstract}

Key words: bubble aerator, dissolved oxygen, paddle wheel aerator, water temperature difference

\section{INTRODUCTION}

Aquaculture is one of the important industries in east and south-east Asia. Shrimp aquaculture is the most popular aquacultural products in the world. In such aquacultural ponds many of the aquacultural farmers have installed the aerator in their ponds to improve the ponds environment. Mainly two types of the aerator have been installed in the aquacultural ponds, paddle wheel type and bubble type. The function of the aerator is to induce circulation and to supply dissolved oxygen (DO). Many of the researchers have reported the usability of the aerator and estimated the performance of the aerator with various aspects in the previous (e.g. G. L. Rogers, 1989; C. E. Boyd, 1998). These researches contribute the improvement of aeration performance and as these results many idea for the operation of aerator have been proposed (e.g. T. Ahmad and C. E. Boyd, 1998; S. Moulick et al., 2005; S. Moulick1 and B. C. Mal, 2009). However, it is also remaining fact that the fuel cost of the aerator immiserate the farmers (S. Piumsombuna et al., 2005) since there are no criteria for operating the aerator, and as this result the farmers run the aerator empirically. Additionally, the fuel price has been increased rapidly in the past several years. These mean that the operating methods of the aerator which are well known among the farmers might damage the both farming management and nature environment. For these reasons, it is important to know the usage habits of the aerator and to verify its impact on the

\footnotetext{
1 Faculty of Fisheries Kasetsart University, Thailand

* Corresponding author (E-mail: a-ozaki@agr.kyushu-u.ac.jp)
}

ponds water quality.

In the present study in order to perceive the usage habits of the aerator, we conducted hearing survey at Samut Songkram Province, Thailand. In addition, in order to verify the impact of the aerators on ponds water temperature and dissolved oxygen, we conducted operation experiments of the aerator.

\section{METHODS}

\section{Survey for Usage of the Aerator at Samut Songkram Province, Thailand}

In order to know the usage habits of the aerator, we conducted hearing and observing survey at Samut Songkram province, Thailand. Location information of Samut Songkram province is shown in Fig. 1. Objective person of the survey were fifteen owners of aquacultural ponds. Hearing items and the answer are shown in Table 1. All of the farmers cultured Tiger Shrimp. Twelve farmers used paddle wheel aerator, three farmers didn't use any aerator. No farmers used the bubble aerator in this area because the bubble aerator was popular for the southern parts of Thailand farmers. The objectives of using the aerator could be seen mainly to improve the water quality and to activate the products. Operating way of the aerator were divided on several types, five farmers used night term only, five famers used twenty four hours continuously and two famers used after rain. In addition some of the farmers mentioned that there were some recommended operating methods by feed shop of the aquaculture but nobody used this recommended method because of the laborious. Regarding the operating of the aerator, most of the 

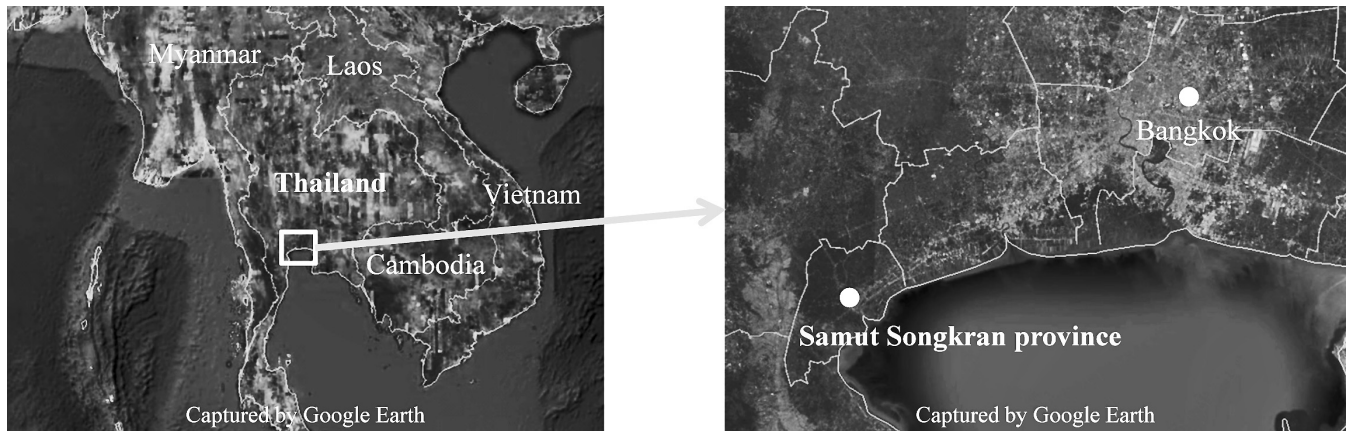

Fig. 1. Location information for Samut Songkram province, Thailand.

Table 1. Quarry and answer for aeration running

\begin{tabular}{lc}
\hline \multicolumn{1}{c}{ Quarry } & Ans. \\
\hline Q.1 What do you culture in your ponds? & \\
Prawn (tiger shrimp) & 15 \\
\hline Q.2 What Kind of aerator do you use? & 12 \\
Paddle wheel & 0 \\
Bubble aerator & 3 \\
Without aerator
\end{tabular}

Q.3 Why do you use aerator?

$\begin{array}{ll}\text { To make a circulation flow } & 8 \\ \text { To increase dissolved oxygen } & 7 \\ \text { To improve a water quality } & 5 \\ \text { To activate the shrimp } & 5\end{array}$

Q.4 How long do you use aerator?

Night term only 5

Continuously running for 24 hours

After rain (in rainy season)

\section{Q.5 What is the problem of running aerator?}

Fuel cost is expensive

Running term is difficult

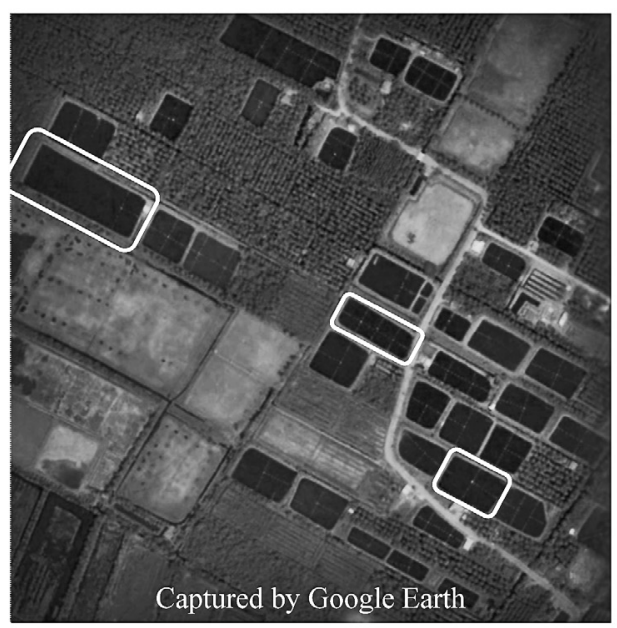

farmers concerned about the fuel cost for the aerator. On the other hands, there were various setting conditions of the aerator as shown in Fig. 2. The setting conditions of the aerator were also divided on their original methods, some farmers set only edge of the ponds, and the other famers set widely on the water surface, etc..

\section{Operation Experiments of Aerator}

In order to verify the impact of the aerator on ponds water quality, especially for the temperature and dissolved oxygen variations, we conducted operation experiments of the aerator. We conducted observation on $21^{\text {st }}$ to $23^{\text {rd }}$ of March 2010 at the experimental ponds in the Samut Songkram Fisheries Research Station, Faculty of Fisheries Kasetsart University, Thailand. The ponds design, measurement items are shown in Fig. 3 and Table 2. We operated Paddle Wheel aerator and Bubble aerator in Pond A and Pond B respectively. Regarding the Paddle Wheel aerator, we used four paddle wheels. The diameter of wheel was $650 \mathrm{~mm}$ and one unit had eight blades. The width of the blade was $185 \mathrm{~mm}$ and about $5 \mathrm{~mm}$ of the blades were into the water. The distance of each paddle was $530 \mathrm{~mm}$ (edge wheel to center wheel) and $700 \mathrm{~mm}$ (center wheels). On the other hands, regarding the bubble aerator, we used tubes connected with induction motor. The tubes were set at the bottom of the pond. The inside diameter of the tube was

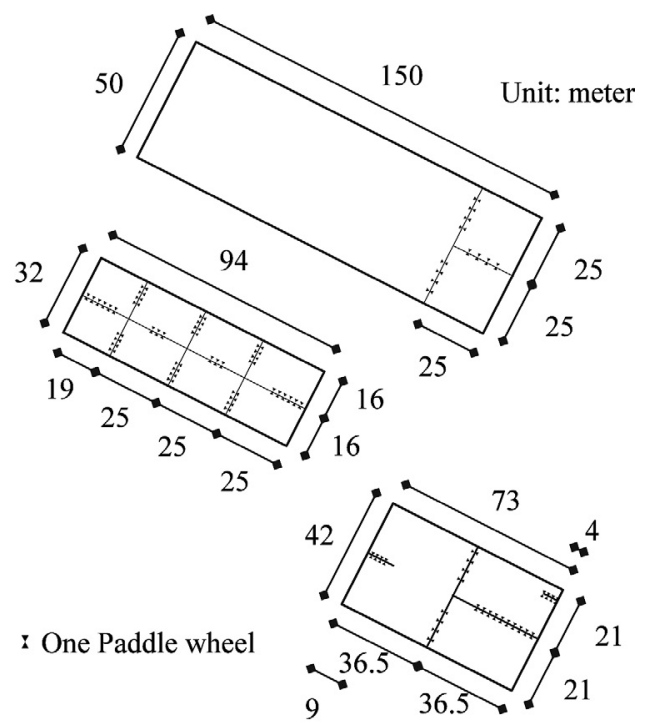

Fig. 2. Example image of setting conditions of the aerator at Samut Songkram province. 
Table 2. Measurement items and interval

\begin{tabular}{lll}
\hline & Measurement Items & Measurement Interval \\
\hline & Air Temperature (degree Celsius) & \\
& Humidity (\%) & 2 minutes \\
Meteorological Data* & Wind Velocity (m/s) & \\
& Wind Direction (fegree) & \\
& Solar Radiation (W/m²) & \\
\hline \multirow{3}{*}{ Water Quality Data } & Water Temperature** (degree Celsius) & 2 minutes \\
& Dissolved Oxygen Level*** (mg/l) & 3 hours \\
\hline
\end{tabular}

* We set the weather station at $10 \mathrm{~m}$ above from water surface

** We used thermocouple data logger

*** We used handy type DO level sensor
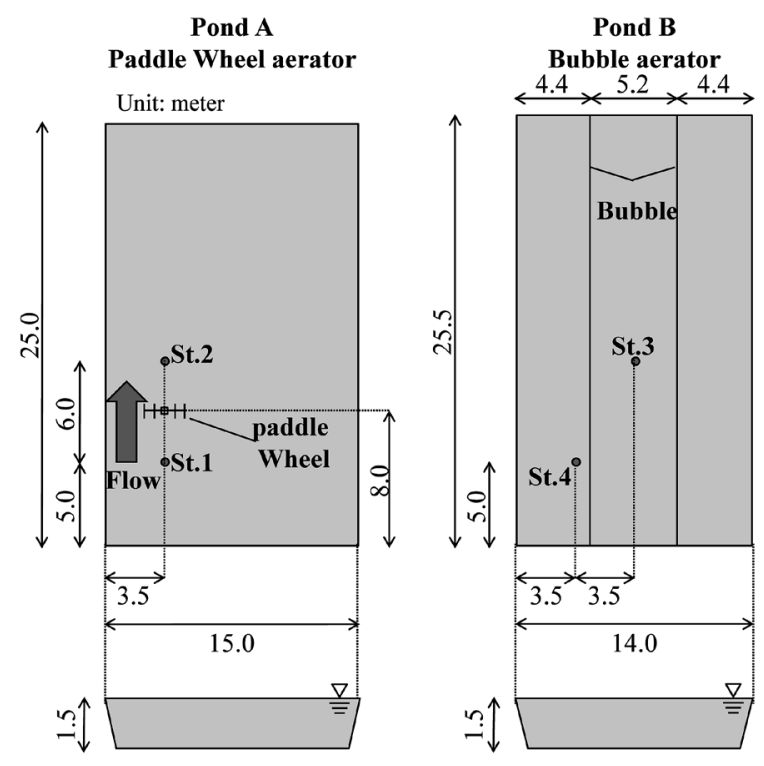

Fig. 3. Ponds design for the experiments.

Table 3. Running conditions of aerator

\begin{tabular}{c|c|c|c|c|c|c}
\hline \multicolumn{7}{c}{ Operating condition of aerator } \\
\hline \multicolumn{2}{c|}{ Day 1 } & \multicolumn{6}{c}{ Day 2 } \\
\hline $21^{\text {st }}$ & $22^{\text {nd }}$ & $22^{\text {nd }}$ & $23^{\text {nd }}$ & $23^{\text {rd }}$ & $23^{\text {rd }}$ & $23^{\text {rd }}$ \\
March & March & March & March & March & March & March \\
15:00 & $15: 00$ & $16: 00$ & $8: 00$ & $10: 00$ & $12: 00$ & $15: 00$ \\
\hline Run & Stop & Run & Stop & Run & Stop \\
\hline
\end{tabular}

$25 \mathrm{~mm}$ and we made $2 \mathrm{~mm}$ diameter holes on the tube for the aeration. The distance of the holes was $500 \mathrm{~mm}$. The output of the induction motor was $1.5 \mathrm{~kW}$. In order to keep the conditions of two experimental ponds equally, we dried the ponds one month before experiments and irrigated 3.0 ppm salt water into experimental ponds one week before experiments. In the experiments we separated the observation term into two days parts. First day we did not use aerator (non-operating term) and second day we intermittently used the aerator (operating term). Operating condition of the aerator is shown in Table 3.

\section{RESULTS}

\section{Meteorological data of observation term}

Fig. 4 shows the meteorological data of observation term. Left side parts show the results obtained at first day (Day 1 non-operating term) and right side parts show the results obtained at second day (Day 2 operating term). From the observation results, we could see some characteristics of meteorological variation at Samut Songkram as follow; 1. The temperature differences between maximum and minimum temperature were about six degree Celsius. 2. Wind velocity was strong from noon to midnight, however wind velocity was decreased gradually from midnight to sunrise. 3. Wind direction was almost one way direction from south to north.
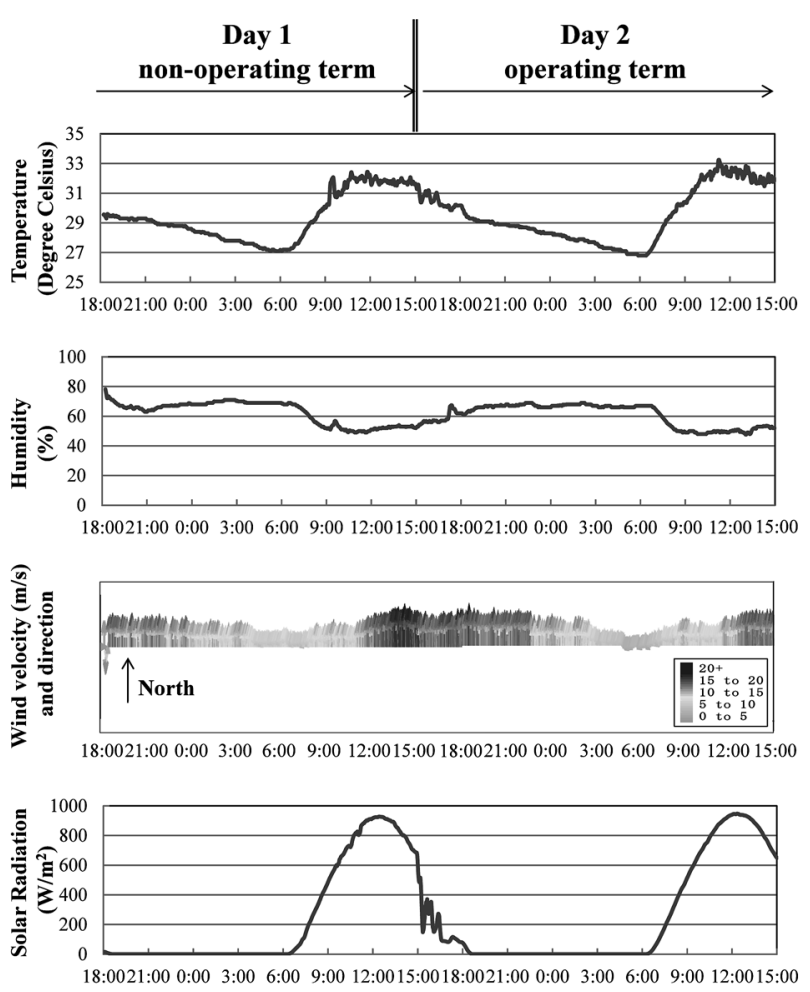

Fig. 4. Meteorological data of observation term. 
From above 3 findings it is considered that the temperature difference between day and night terms might form temperature stratification in the ponds. In addition, strong wind velocity, especially from noon to midnight, had a possibility to break the stratification.

\section{Temperature and DO variation in non-operating term}

Fig. 5 shows water temperature variations for verti- cal direction obtained at non-operating term Day 1 . Both ponds and each measurement points had same tendency. In the night term, the surface layer temperatures were the lowest and the temperature differences between layers were decreased with the passage of time. Before sunrise, the temperatures of each layer were almost same. These tendencies might be the impact of strong wind in the night term. Therefore, it is considered that the strong wind such seen at Samut Songkram
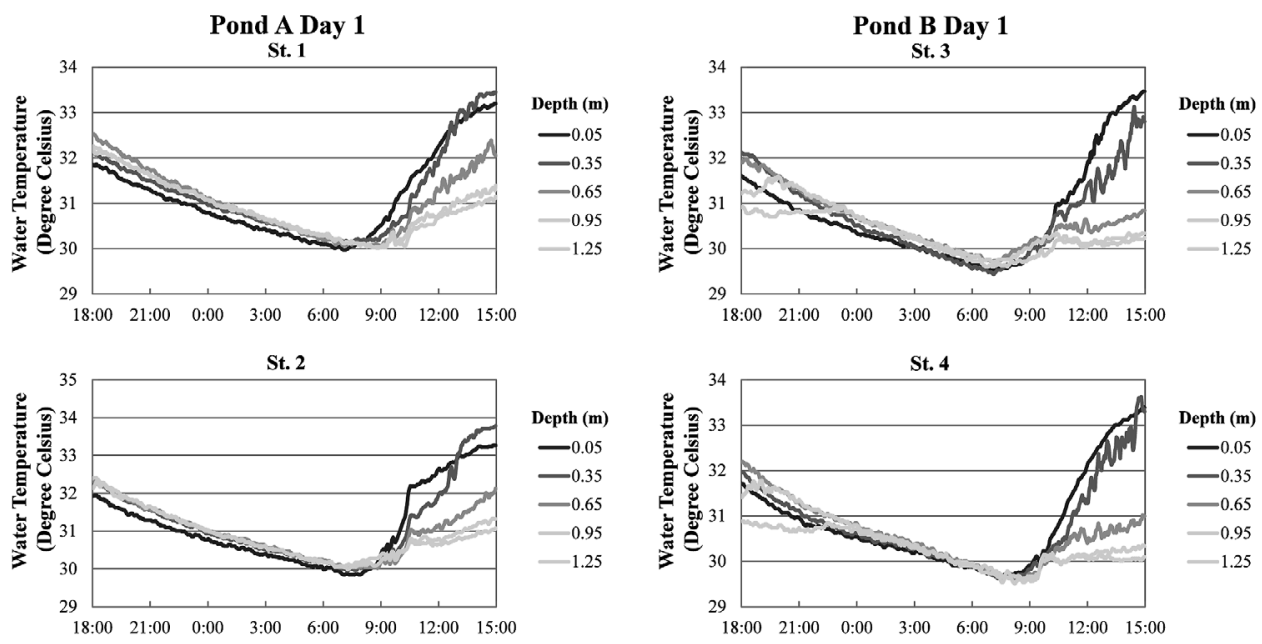

Fig. 5. Water temperature variations for vertical direction with time (obtained at Day 1).

\begin{tabular}{|c|c|c|c|c|c|c|c|c|}
\hline \multirow{2}{*}{ Surface } & \multicolumn{8}{|c|}{ Pond A St. 1 Day 1} \\
\hline & 18:00 & 21:00 & 0:00 & 3:00 & 6:00 & 9:00 & 12:00 & 15:00 \\
\hline \multirow{5}{*}{ 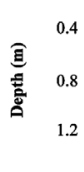 } & 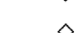 & 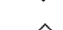 & 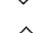 & ( & $\hat{~}$ & 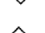 & 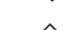 & 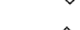 \\
\hline & $\diamond$ & $\diamond$ & $\diamond$ & $\diamond$ & $\diamond$ & $\diamond$ & $\diamond$ & $\diamond$ \\
\hline & $\diamond$ & $\diamond$ & $\diamond$ & $\diamond$ & $\diamond$ & $\diamond$ & $\diamond$ & $\diamond$ \\
\hline & 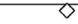 & $\xi$ & $\nabla$ & 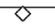 & $\diamond$ & $<$ & 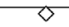 & $\diamond$ \\
\hline & $\diamond$ & $\diamond$ & $\diamond$ & $\diamond$ & $\diamond$ & $\diamond$ & $\diamond$ & $\diamond$ \\
\hline
\end{tabular}

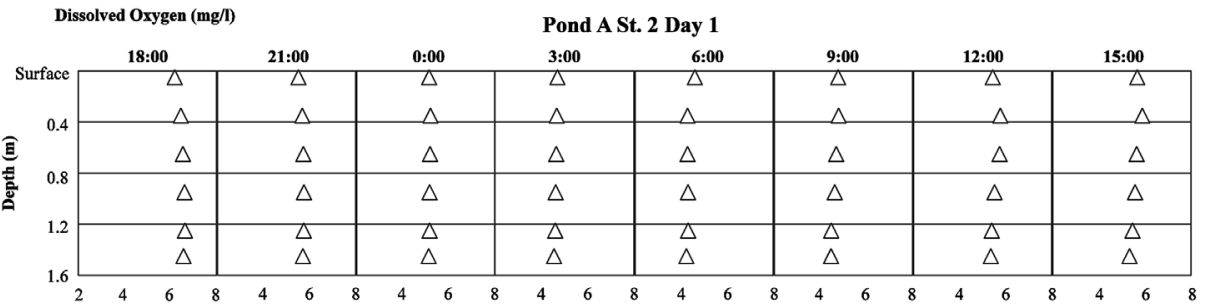
Dissolved Oxygen (mg/l)

\begin{tabular}{|c|c|c|c|c|c|c|c|c|}
\hline \multirow[b]{2}{*}{ Surface } & 18:00 & 21:00 & 0:00 & 3:00 & $6: 00$ & 9:00 & $12: 00$ & $15: 00$ \\
\hline & $\checkmark$ & च & 5 & $\square$ & v & च & v & $\square$ \\
\hline \multirow{4}{*}{$\begin{array}{l}\text { 目 } \\
\text { 言。 } \\
\text { 音 }\end{array}$} & ــ & ــــــ & ــ & ــ & ـــ & ــ & ــــ & ــ \\
\hline & $\square$ & $\square$ & $\square$ & $\square$ & $\square$ & 口 & $\square$ & 口 \\
\hline & $\square$ & $\square$ & $\square$ & $\square$ & $\square$ & $\square$ & $\square$ & $\square$ \\
\hline & $\square$ & $\square^{\square}$ & $\square$ & $\square$ & $\begin{array}{l}\square \\
\square\end{array}$ & $\square$ & $\square$ & $\square$ \\
\hline
\end{tabular}
Dissolved Oxygen (mg/)

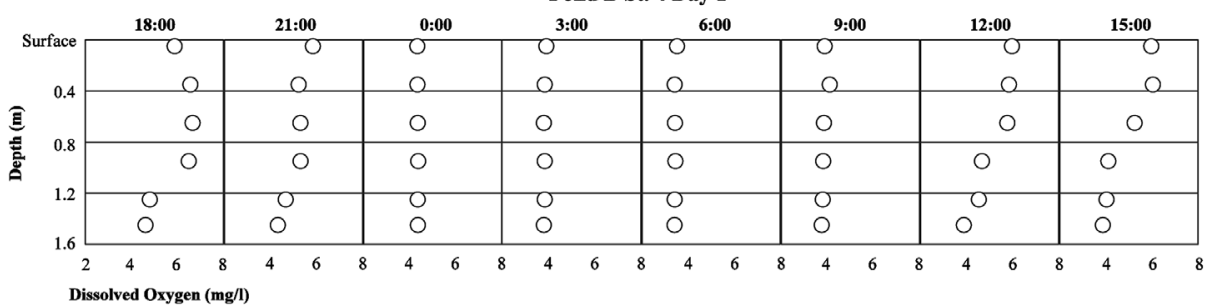

Fig. 6. Dissolved oxygen variations for vertical direction with time (obtained at Day 1). 
have a possibility to disturb the temperature differences in shallow ponds. On the other hands, we could see clear temperature differences between upper and lower layer after sunrise. The surface layer temperatures were highest and maximum temperature differences between layers were around three degree Celsius at 15:00. From these results, it is considered that the meteorological conditions at Samut Songkram province generate and disperse the temperature differences in a day.
Fig. 6 shows dissolved oxygen variations for vertical direction with time obtained at non- operating term Day 1. It was obvious that the overall DO level of the night term was decreased with time. This was due to respiration of aquatic organisms. Although the strong wind was continued during night time, the DO level was decreased at both ponds and each measurement points. These meant that the DO consumption by respiration was much higher than the capacity of DO supply by
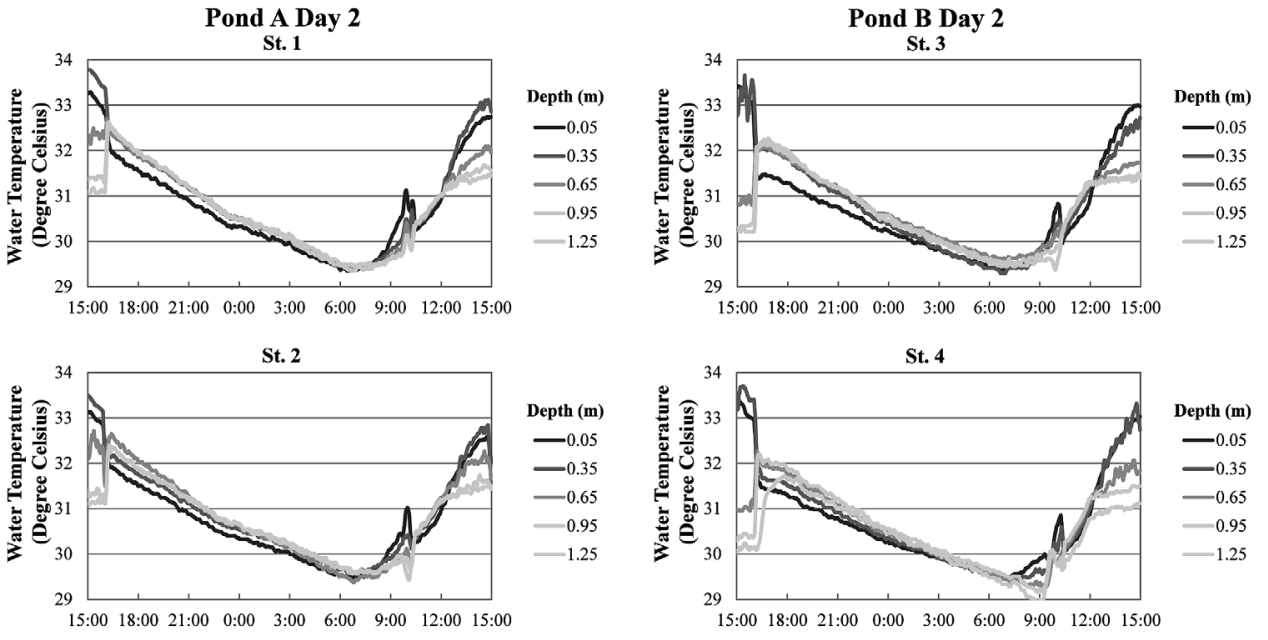

Fig. 7. Water temperature variations for vertical direction with time (obtained at Day 2).
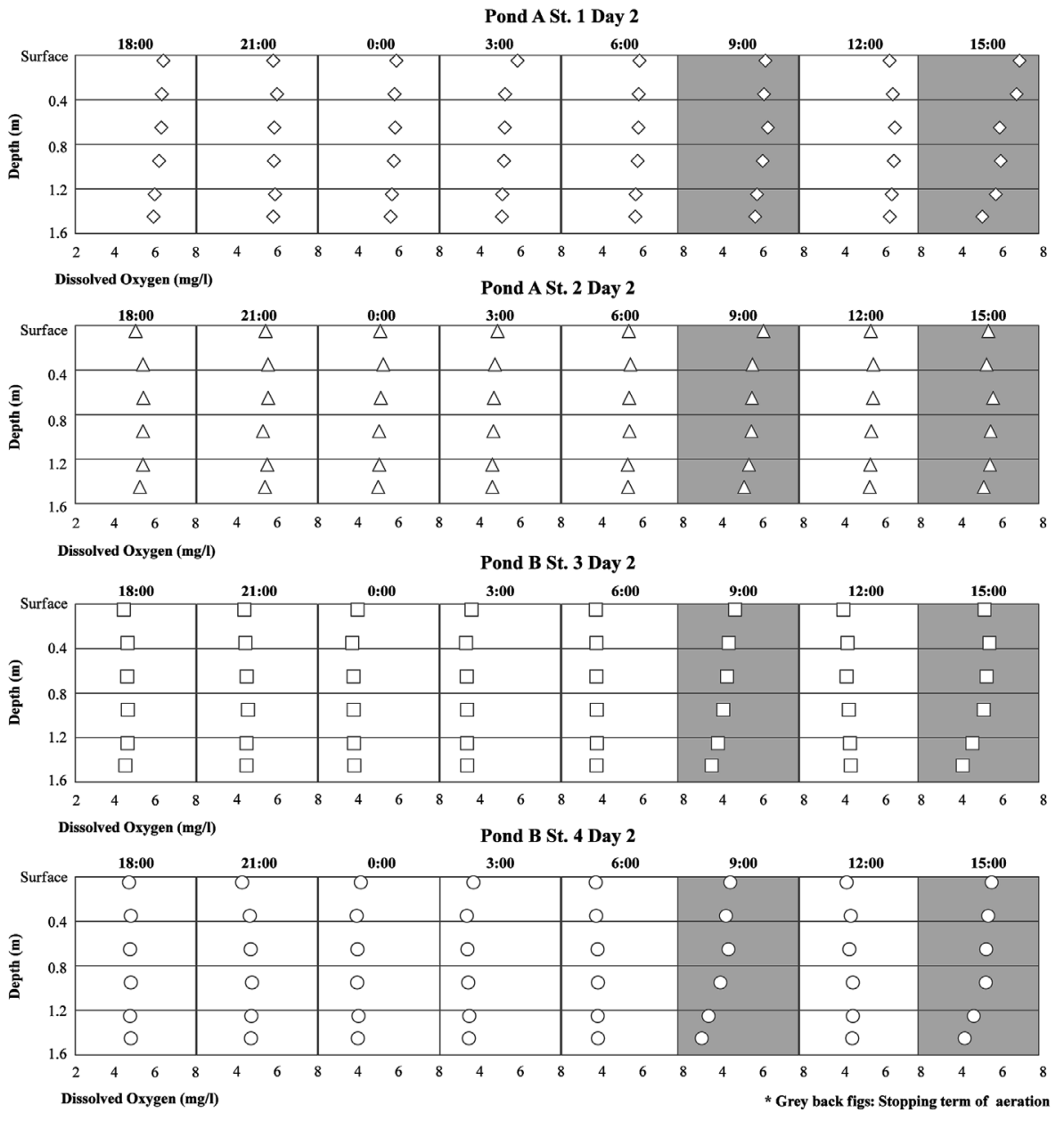

Fig. 8. Dissolved oxygen variations for vertical direction with time (obtained at Day 2). 
wind. On the other hands, DO level was increased after the sunrise by photosynthesis of phytoplankton, however, the lower layer kept the low level DO. This was considered due to the DO consumption by benthonic organisms at bottom mud.

\section{Temperature and DO variation in operating term}

Fig. 7 shows water temperature variations for vertical direction obtained at operating term Day 2. Before operating the aerator at 16:00, we could see the temperature differences between upper and lower layer, however the differences were disappeared after the operation except surface layer. The temperatures at surface layers might have been impacted the air temperature and wind. As we mentioned in Table 3, we stopped the both aerator from 8:00 to 10:00 and 12:00 to 15:00. In these stopping terms, we could see the regeneration of the temperature differences between upper and lower layer. However, as compared with non-operating term the temperature differences between layers were low. On the other hands, we could not see the differences of aerator types. Both aerators impacted on the temperature variations in the ponds comparably.

Fig. 8 shows the dissolved oxygen variations for vertical direction with time obtained at operating term Day 2. In Fig. 8, gray parts figures show the data obtained at stopping term of the aerator. It was obvious that both of the aerator made vertical DO level uniform during the operating term. However, the supply performance of DO by both aerators was not enough as compared to non-operating term Day 1 . We could see the differences of aerator types in the night term, the DO levels obtained at paddle wheel aerator pond (St. 1,2) were higher than the DO level obtained at bubble aerator pond (St. 3, 4). This meant that the capacity of DO supply by paddle wheel aerator was much higher than the bubble aerator. On the other hands, the DO levels at bottom became low during stopping term of the aerator.

\section{DISCUSSIONS}

In the present study in order to perceive the usage information of the aerator and to verify the impacts of the aerators on water temperature and dissolved oxygen in a ponds we conducted both hearing and observing survey for usage of the aerator and operation experiments of the aerator.

From the results of hearing and observing survey, we could conclude that most of the aquacultural famers understood the effect of aerator in their ponds, however they didn't know the way of setting and management of the aerator. They run the aerator based on their experience. This empirical usage of the aerator might increase the fuel cost of operating the aerator and might impact the natural environment. Therefore, it is important to propose some criteria for operating and setting of the aerators.

From the operation experiments, we could get two important findings; one was the impact of the wind on temperature differences between layers and another was the impact of the aerators on DO level.

Regarding the impact of the wind, we could see the uniform capacity of thermal stratifications by wind. The strong wind in the night term could disturb the temperature differences between layers. This wind impact might be particular impact only in the night term since the night term water temperature was not impacted by solar radiation. However, the farmer might not need to operate the aerator during night term with strong wind.

On the other hands, regarding the impact of the aerators on DO level it was clarified that the both paddle wheel and bubble aerator had uniform effect for the DO level in vertical direction. However, we could not see enough supply performance of DO by both aerators. This reason was conjectured that the aerators had disturbed the bottom mud in the ponds, and disturbed mud might have had some effect on dissolved oxygen consumption. Disturbing impacts of the bottom mud is also one of the important role of the aerators, however if we considered the ideal performance of the aerators it would be important to clarify the relation between ponds scale, operation power of aerator and DO variation.

From these above findings, we could summarize the present study as follow;

1. For the operation of the aerator, a certain criteria including setting, operation and management conditions would be needed.

2. In order to save the management cost of the aerator and to reduce the impact on natural environment, the aquacultural farmer may be able to stop the aerator during strong wind term.

3. For ideal performance of the aerator, operation and setting plan which is well considered about ponds scale, aerator power and preferable environment of the aquacultural products would be needed.

\section{ACKNOWLEDGEMENT}

This research was supported by the Faculty of Fisheries, Kasetsart University and Japan Society for the Promotion of Science (JSPS). The authors wish to acknowledgement the help and advice received from the staffs and students of Kasetsart University.

\section{REFERENCES}

Ahmad, T. and C. E. Boyd 1998 Design and Performance of Paddle Wheel Aerators. Aquacultural Engineering, 7(1): 39-62

Boyd, C. E. 1998 Pond water aeration systems. Aquacultural Engineering, 18(1): 9-40

Moulick, S., S. Bandyopadhyay and B. C. Mal 2005 Design Characteristics of Single Hub Paddle Wheel Aerator. Journal of Environmental Engineering, 131(8): 1147-1154

Moulick, S. and B. C. Mal 2009 Performance Evaluation of DoubleHub Paddle Wheel Aerator Journal of Environmental Engineering, 135(7): 562-566

Piumsombuna, S., M. A. Rabb, M. M. Deyb and N. Srichantuka 2005 The Farming Practices and Economics of Aquaculture in Thailand. Aquaculture Economics \& Management, 9(1-2): 265-287

Rogers, G. L. 1989 Aeration and circulation for effective aquaculture pond management. Aquacultural Engineering, 8(5): 349-355 